\title{
新体系物理学により提案された高温超電導発生機構の 易しい解説と実験的研究第一報
}

帝京大学真学部物理学教空 飯田修一*、光井俊治、阿部清、松原直美**

Shuichi Iida, Toshiharu Mitsui, Kiyoshi Abe and Naomi Matsubara: An Easily Understandable Explanation of the Possible Enhancement Mechanism of the High Temperature Superconductivity of Oxides Proposed by the New Frames in Physics and the First Report of Our Experimental Studies on BiPbSrCaCu-0 System.

Since the new frames in physics present a divergenceless mathematical framework for the interaction between the electron fields and the zero-point photon fields, they provide a powerful tool for the analysis of the mechanism of the superconductivity. The minimal coupling effective Hamiltonian predicts that the interaction of a single electron field with a normal-mode of the photon can raise its amplitude by a magnitude of more than 10-7, so that, by the participation of the superconductive electron fields of more than 107 in the number, and, under the action of the proposed possible $Q$ enhancement of the mesoscopic in-crystal resonator, a good possibility is present that a unified complex of the electron fields and the zero-point photon fields is cooperatively created in the specimen. Since this mechanism is spin-independent and has no direct relation to the phonon modes, no isotope effect nor serious effect from the magnetic ions is expected. Different from metals, since the oxides have the ionic lattice which is more rigid and more difficult to be excited by the photon fields, the coupling between the resultant electron-photon field complex and the thermal modes of the phonon fields of the lattice should be much smaller.

( Received J une 18,1988)

$\mathrm{YBa}_{2} \mathrm{Cu}_{3} \mathrm{O}_{7} に 90 \mathrm{~K}$ クラスの)高温超電尊が発見され、更にBi $\mathrm{Sr}_{2} \mathrm{Ca}_{2} \mathrm{Cu}_{3}-0$ 系、 $\mathrm{Tl}_{2} \mathrm{Ba}_{2} \mathrm{Ca}_{2} \mathrm{Cu}_{3}-0$ 潘など

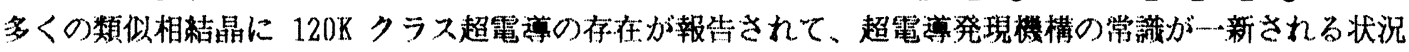
が進展している。ところで、従来の）BCS 理論は、局所的な格子站動（Phonon）を媒介として、超電導電 子間に協力的相互作朋が発生し、クーパー・ペアとエネルギー・ギャップが形成される事を骨子とする。

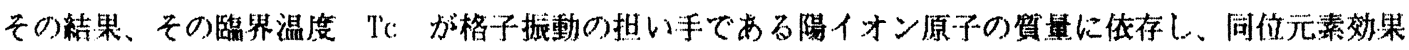
が期待され、金属超電尊体に関してその実測值との一致を見ている。ところが、酸化物超電尊体では、 此の同位元素効果が殆ど無い。更に全ての超電递体物質の同詣元素効果を图表にすると、それは I'c

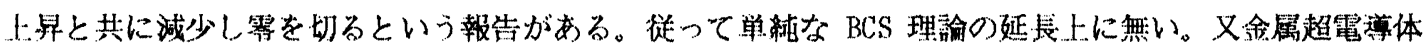

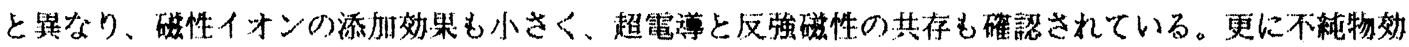
果も小さく、酸素イオンの不規則配列の存在など、一旦超電尊相が形成されると、超電亳は構造敏感量 では無い上うに見える。さて、電子のVRモデル（Vortex Ring, 永久電流㽞）を重要な基礎として、新体 系物理学が建設され、朕来漠然としか理解されていなかった古典物理学と量子物理学の数理物理学的連 結構造が、㴊密な数等体系で明示された。その結果、VRモデルを使用し、相対論的最小作用の原理によ

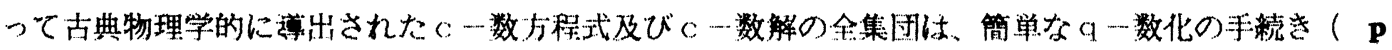
$\rightarrow(\hbar / i) \nabla, E \rightarrow(-\pi / i) \partial / \partial t$ 、スピン角連動量デンソル $s^{\mu \nu}=\hbar\left(\gamma^{\mu} \gamma^{\nu}-\gamma^{\nu} \gamma^{\mu}\right) / 4 i$ など〔マはディラックの 移行する。q-数方程式と q-数解は何れも演算子（operator）なので、それにより演算される状態関 数が付加されて、量子物理学の全体系が形成される。腿来と異大り、電子のc一数像が有限の大きさ

*(果京大学名賞教授)、**薬学部学生 
(半径 ${ }^{\circ} \mathrm{R}=\mathrm{gh} / \mathrm{mc}=0.00773185 \AA$ ) )を持た、スビン角運動菓と磁気能㴖を自藏し、電磁自 已エネルギー無限大の、いわゆる発散の困䧼が無く、徉つて、量于物理学の最深部に関係する物理学の

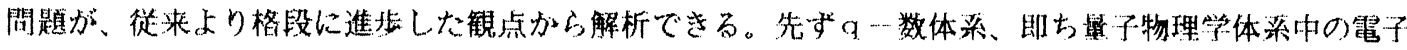
孝示すもは、シュレディンガー・ディラック流の波動関数そのものであって、点とか、永久電流摆(

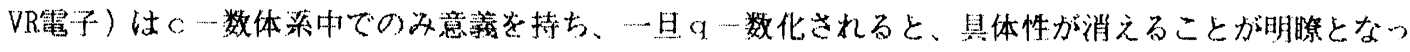
た。この波動関数そのもので示された電子を「電子埸」（Electron Field）と呼び、ボルン流の)粒計碓 率波の考之左は、電子場が微視的な範国に広がっている限り強調されない。これが、電子に対して新物

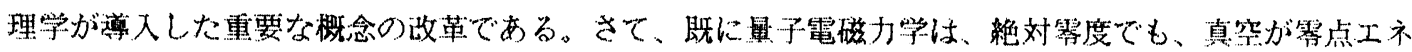
ルギー状熊で榇動する電磁䡚射場、“光子場”、で充ち充ちていることを尊出しているが、この光子場

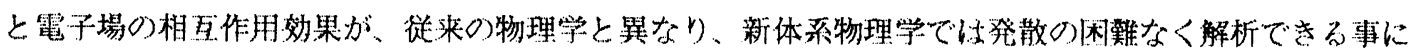
なった。その結果電子の静江エネルギー $\mathrm{mc} 2$ 虫、光子場との相互作朋に上り、10-6の浙だけ小さくな

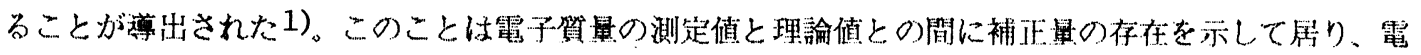
子の暴常磁気能率の第一次補正項（VR電子はc- - 数段階で $\alpha / 2 \pi \sigma$ 第一次補泟項を正確に持っている。1)

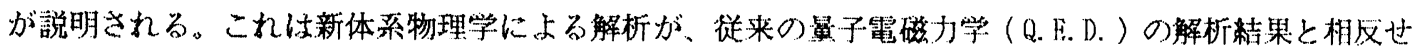
ず、両立することを示す一つの事実である。このとき用いた電子場と光子場の相互作用の解析方法は、 原子やイオンが電磁波老吸収したり、電磁波圭発射したりする際の咲来の解析方法と ${ }^{2}$ 形式的には同等

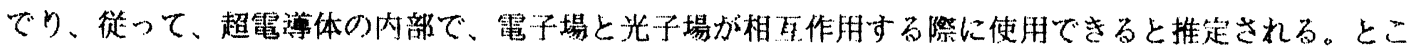
ろで、超電尊体が䊀む電子埸と光子場との相互作用の重要な㬰験測定例として、西独マックス・プラン

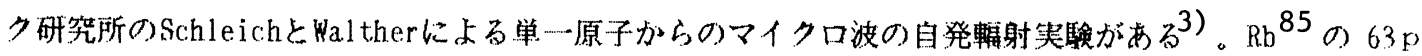
$3 / 2 \rightarrow 61 \mathrm{~d}_{3 / 2}$ の遷移に伴う輻射であるが、単一原子を超電導体Nbで作られた共振空洞中に尊くこと により、その自発㬏射確率は、その空洞の）（傎、8 $810^{8}$ (2K)、倍だけ增幅されたことを報告してい る。この䊅果枯、空洞中でその共振モードの電磁波の零点振動の振幅が、超電尊体空洞壁内の電子埸と の相互作用により、Q倍されたものと理解される。）重要点は共振筀洞中では量子摇動電磁波のモード が変化し、共振しないモードの零点振動の振幅は激诚し、共振するモードの零点振動の振幅は10 ${ }^{9}$ 倍と いった形で激增することである。この辺の数理物理学的解析は、道常のQ.E. D. の解析 ${ }^{2)}$ 上り高度なもの で、連粋スペクトラムを不連続スペクトラムで近似する数理物理学上の問題が䊀むことを注意する。し かしながら、この事実怯、通常のマイク口波用共振空洞が、外界よりの電磁波の侵人を遮断し、その内 部ではさその共振モードのみを保有して、それ以外のモードを許さないという確認された巨視的 $\mathrm{c}$ 一数的

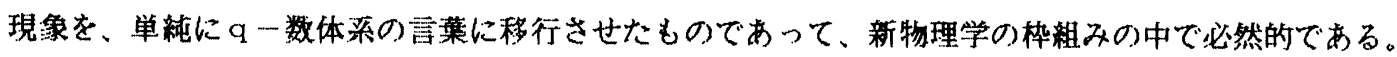

従って、一般に超電 尊電子群 )電子場と 零点振動光子場とは 湤しく相互作用する と䊅論される。さて 高温超電尊体 $\sigma$ 典型 例として、YBa ${ }_{2} \mathrm{Cu}_{3} \mathrm{O}_{7}$ を取ると、イオン結 晶を基整としており、 陽イオンと陰イオン

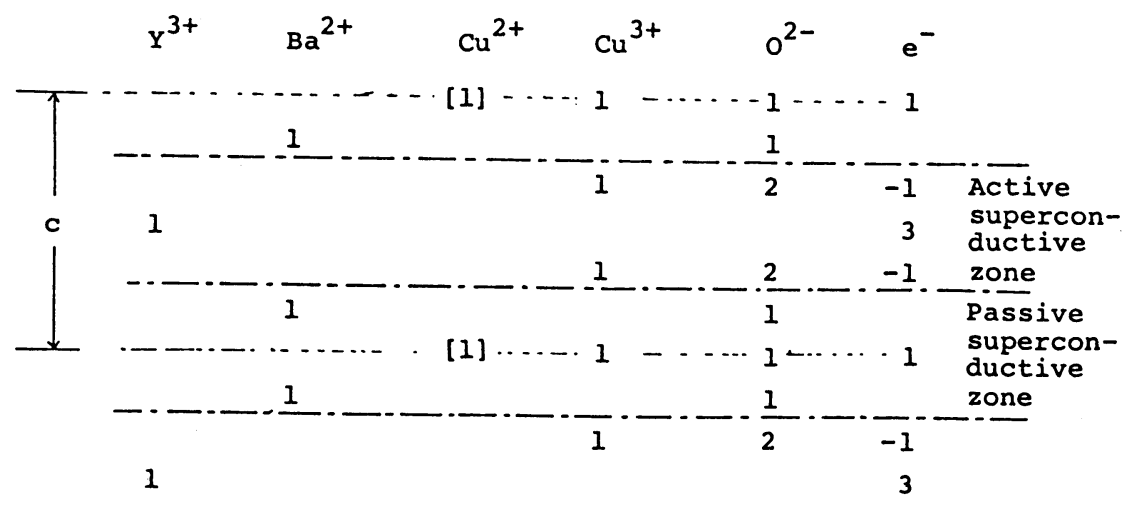


が共存し、イオン性の

維合を持っている。

Diagram 1 に本諭文の

観点に立つ $\mathrm{YBa}_{2} \mathrm{C}^{\mathrm{C}} \mathrm{u}_{3} \mathrm{O} 7$ の粘晶構造が示される。

結昆はc軸に沿って缯

状構造老取る。金属酸

化物の)常識に従って4)、

Diagram 1. The layered structure of $\mathrm{YBa}_{2} \mathrm{Cu}_{3} \mathrm{O}_{7}$, as shown along the c-direction. The unit cell constant, $c$, is about $11.68 \mathrm{\AA} . \mathrm{e}^{-}$indicates the electron and -1 means that the four additional electrons of $2 \mathrm{O}^{2-}$ are reduced effectively to three by the attractive electric field of $\mathrm{y}^{3+}$ ion. Electric charge neutrality of each layer is assumed in the construction of the diagram. The bracket, [ ], indicates the nonsuperconductive case where the non-magnetic $\mathrm{Cu}^{3+}$ and one superconductive electron are replaced by a magnetic $\mathrm{Cu}^{2+}$ ion.

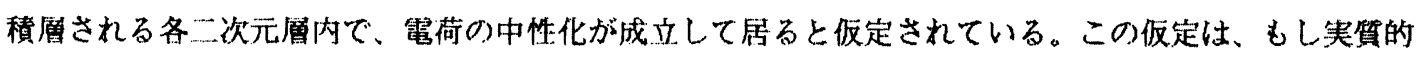
にそうでなかった場合、非常に強い電場が発生することから、妥当なもので、磁性酸化物で実証されて，

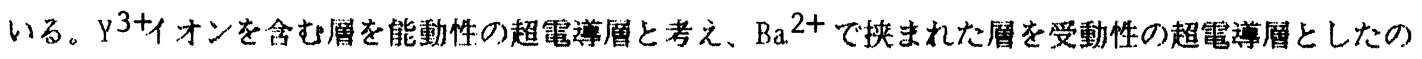

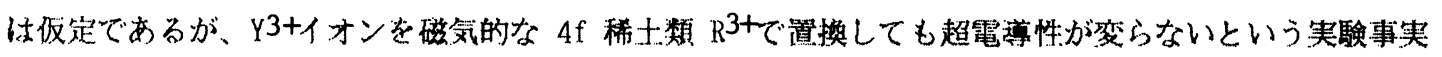

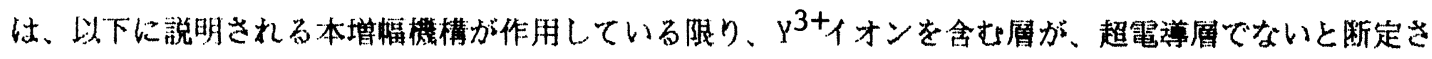
せない。本解析では、Diagram 1.にその一例が示されたような形式で、そのイオン性結晶格子の上に超 電導電子群が形成されると考える。そうした上で、結晶格子を無視し、一個の超電尊電子に着目し、そ の電子場と、超電尊体内の零点振動光子場との相互作用を一般諭で取り扱う。電子場と光子場を考之る

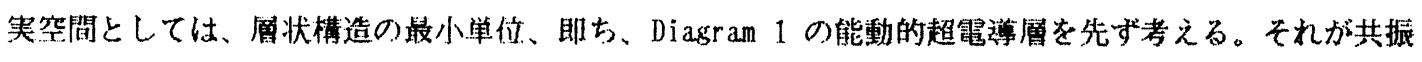
空洞老形成するか否かは、通常の変体壁を持つ真空空洞とは異なり、電尊電子群が空洞内部そのものに 分布しているので、一義的には断定できないが、他の㕌の電子場との相互作用をも考虑した上で、磁区 構造やマイクロ波の共振空洞中のモードに類似した定在波モードが形成されるものと仮定する。この㻮、

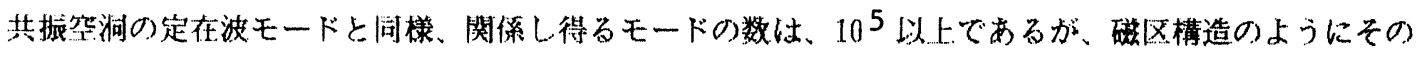
内の一つを協力的に選択するかどうか仗判らない。さて、光子場の生成・消隇演算子を使用し、かなり

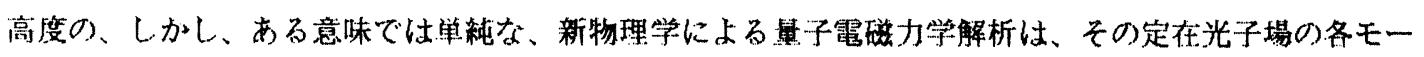
ドの振幅が、一電子当り 10-7以上程度励起され得ることを子予する。此の堌幅は更に二つの因子で昖大 される。一つは関与する電子の個数であって、周の広がりが 1 ル以上と考えると、関係電子数は $10^{7}$ 個 以上になる。第“汢酸化物としての共振空間のＱ值の関与した協力現象的増幅である。先述の西独Sh-

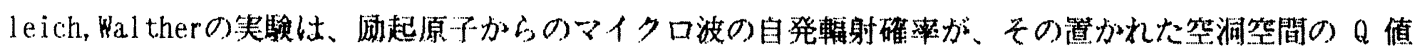
に比例し、Nb超電尊壁空洞の場合、 $2 \mathrm{~K}$ で、Q $Q=8 \times 10^{8}$ 倍の碓率の增大を観測している。我々の場合、関

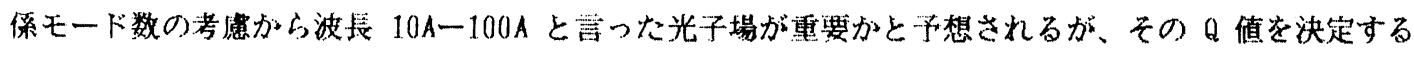
のは熱振動格子場との粘合の強さであるう。それについては按はど説明する。しかし、たとえ波長に比 例して減少するとして $10^{2}$ 倍の增幅でも重要である。こうして增幅された零点電磁埸の振動を媒介とし て、多数倜の電子埸と光子場のコヒーレントな複合摇動体状況が形成されると推定する。この複合体に おける估相整命状態の一一の描像は、光子埸のEベクトルと整合した電子場、従って、電荷及び電流密

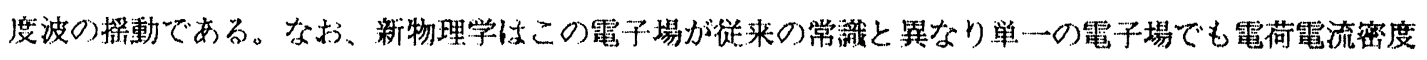
波の採動を持ちうると考之る。この樜構による電子場光子場複合体の汤起は、一旦励起されると、光子 埸の拢幅妁指数関数的に增大するいわゆる協力現象の可能性がある。なお、この複合体の形成により、 電子場山光子埸と整合し、従って光速度で連結され超電尊体全体に及ぶコヒーレントな位相が形成され

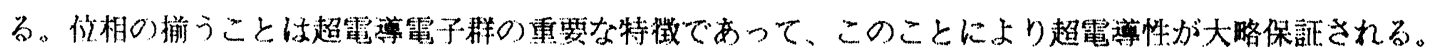
光子場と電子場との位相の整合に関しては、金属・酸化物の差は重要でないと予想される。従って、超 
電尊体の、いわゆる、オーダー・パラメターの担い手は、この光子場電子場複合体の形成にある可能性

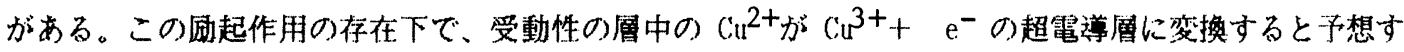
る。C13+の最も単料な描像はスピン零の低スピン状態イオンである。こうして超電尊体の内部には、增 幅された定在波光子場と、それにより修飾され、コヒーレントに全体が整命した多数個の電子群の持つ 電子場による複合体が合成されると考える。この複合体の形成には、熱振動格子場 (Thermal Phonon) との結合が小さく無秩序熱振動系からの影蕀の小さいことが必要である。単純金属では金属陽イオンは 金属状態電子場の中に浮かんでいる。その意味で、100A 以上の波長を持つ光子埸のEベクトルと容易に 結合して一㥞な変位移動を行い得る。ところが、金属間化合物、更に凌化物となると、イオン性と等檑 性の混合した結合状態が形成され、Eベクトルにより容易には動かされないし、又、動くとしても正負 イオンが逆方向に動く光学モードであって、音響モードである熱振動格子場との結合は小さい。従って、 この超電尊機構の存在は、良筫の立方晶金属電尊体が高温超電摹体にならない理由を与える。この機粠 は、Phonon とスビンに関係しないから、同位元素奻果は小さく、クーパー・ペアの形成を妨代ず、磁性 イオンの)存在に鈍感である。クーパー・ペアの形成に関しては、メビュース帯状態 (Mobius' band's

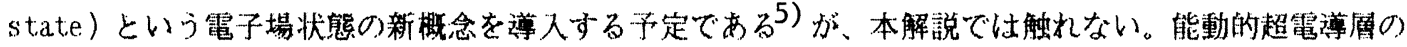
$\mathrm{k}$ 一空間のモード構造と電子個数との関係で、㐿の厚さが厚いはど、関係モード数と関係電子数が增加 し、本權構による增幅が強まると予想される。この予想とそうした物質を人工格子的もしくは結晶化学 的に合成する実験の可能性が、本年初め一月の時点で提起されたが、その将の Bi系、T1系など、新高 温超電尊体の発見とその構造解析山、その予言の正当性を立証して居る上うに思われる。交お、英文の より数学的な解析はプレプリントの形式で1月より 国内外に配布され、その要約の一部仙日本物理学会 第4.3回年会で発表された6)。なお、我々も高温超

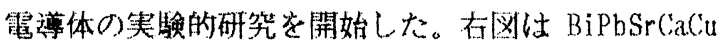
一0系に対するその第一報である。試料はそれぞれの

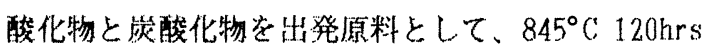
の焼成によって得られな。詳絊な研究報告仿秋の)学 会で行う。なお゙典型的なイオン結昆として、電蓬性 弗化物の研究が必要と推論する。電子埸光子場複合 体の策験的検証も望まれる。

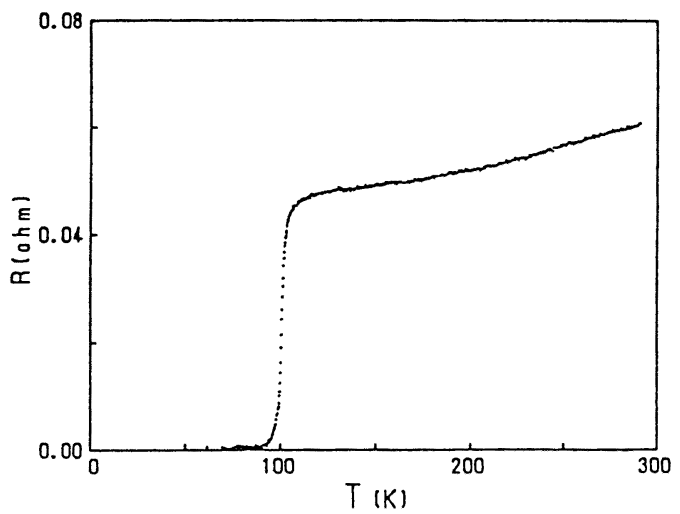

1)、即田修：物性研究編集部に原稿提出(1986)。し办し公表されてい公い。

2)、J. J. Sakurai : “Advanced Quantum Mechanics”, Addison-Hesley Pub. Co., Reading, Mass - et al. (1967).

3). W. Schleich and H. Walther: Proc: 2nd. Int. Symp. Foundations of Quantum Mechanics, I' okyo (1987) p.p. 35, 27.

4 ) S. Iida: J. Phys. Soc. Jpn. 12 (1957) 222.

5). S. Iida : to be puthlished.

6 ）、飯由修：予槁集 3 日本物理学会第43回年会（郡山）(1988） p， 1 . 